\title{
School Accreditation In Disruption Era In Improving Quality Of Education (Case study in Junior High School at Pematangsiantar)
}

\author{
Tumpal Manahara Siahaan ${ }^{1}$, Paningkat Siburian ${ }^{2}$, Din Oloan Sihotang ${ }^{3}$ \\ Lecturer at Universitas HKBP Nomensen Pematangsiantar, North Sumatra \\ Indonesia ${ }^{1}$, Professor di Universitas Negeri Medan North Sumatera Indonesia ${ }^{2}$, \\ Teacher of SMK Swasta Arina SidikalangNorth Sumatera Indonesia ${ }^{3}$ \\ tumpal.manaharasiahaan@gmail.com
}

\begin{abstract}
In the current era of disruption, education is demanded to have good quality so that it can improve the ability to compete with school needs. A school has quality when it has good accreditation scores. In Indonesia, school accreditation is referred to in grades A, B, C. School accreditation for: obtaining an assessment of schools that can be used as a tool for coaching, developing, and improving quality; determine the level of eligibility of a school in providing education services. Schools must be able to improve each other's performance by meeting 8 national education standards. In the accreditation process, a school / madrasah is evaluated in its approval with direction and approval, also prepared for the whole school / madrasah as a place of learning. Although various differences occur in schools / madrasas, schools / madrasas are evaluated according to certain standards. Standards are expected to support and create an atmosphere conducive to the growth of education and provide direction to support oneself that is supported, as well as providing incentives to continue to increase the expected achievements. In accreditation schools / madrasas must recognize their strengths and weaknesses and make continuous efforts to increase their strengths and improve their weaknesses. In this case accreditation has the meaning of the educational process. In addition, accreditation is also an assessment of the results in the form of formal certification of the condition of a school / madrasa that meets certain service standards set by the government. Thus it can be said that the accreditation process in the meaning of the process is the assessment and development of the quality of a school / madrasah on an ongoing basis. Accreditation in the meaning of the results states the recognition that a school / madrasa meets the specified eligibility standards.
\end{abstract}

Keywords: school accreditation; quality; education; impproving; 


\section{Introduction}

In the context of improving the quality of national education in stages, planned and measured according to the contents of Law Number 20 of 2003 concerning the National Education System, CHAPTER XVI Part Two Article 60 concerning Accreditation, the government makes accreditation as a tool to assess the appropriateness of educational units carried out by the National Accreditation Board School / Madrasa (BAN-S/M) with Minister of Education Regulation Number 29 of 2005.

BAN-S / $\mathrm{M}$ is an extension of the government that functions as an independent evaluation body that establishes the appropriateness of education programs and / or units of formal primary and secondary education by referring to national education standards.

In general, efforts to improve quality education have become one of the main government programs called Tri Matra Mutu. The Quality Matrix includes three things, namely: (1) Education Standardization; (2) Education Quality Assurance; and (3) Educational Institution Accreditation

Understanding School Accreditation is a comprehensive assessment process of the appropriateness and performance of educational units and / or programs, which is carried out as a form of public accountability. The school accreditation process is linked to the direction and purpose, and is based on the overall condition of the school as a learning institution (Depdikans, BAN-S / M, 2004).

While the objectives of implementing school accreditation are quoted from the Ministry of Education, BAN-S / M, 2004, as follows:

a) Provide information that a school has or has not met the specified eligibility and performance standards

b) Helping schools conduct self-evaluations and determine their own policies in an effort to improve quality

c) Guiding prospective students, parents, and the community to identify quality schools that can meet individual needs for education including identifying schools that have achievements in a particular field that are recognized by the community.

d) Assist schools in determining and facilitating the transfer of students from one school to another, teacher exchanges, and mutually beneficial cooperation.

e) Helps identify schools and programs in the context of providing government, investment and private assistance and donors or other forms of assistance.

Success or failure of an accreditation implementation policy for an educational institution / school cannot be separated from; 1) the school environment, 2) 
relationships between organizations, 3) available resources, and 4) characteristics of implementing the policy.

Released from the website address of North Sumatra Province BAN SM, data on the results of SMP level accreditation of North Sumatra reports can be seen in Figure 1.

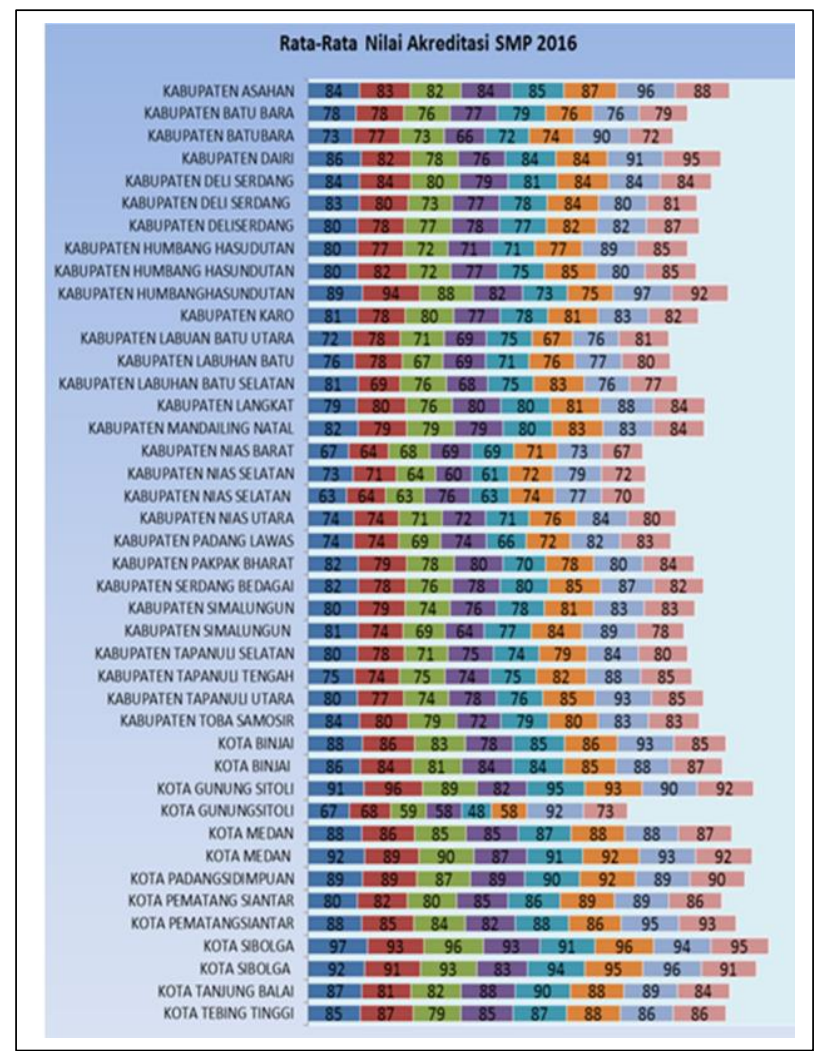

Souce: BAN SM North Sumatra, 2016

From Figure 1, it is clear that the average of 8 standard grades for SMP in each Regency / City of North Sumatra Province can be seen in the graph above. It appears that Sibolga has the highest average standard, while the lowest is owned by Gunung Sitoli. Whereas Pematangsiantar City is at a standard average. From the picture above it can also be seen the magnitude of the variability in the average value of the eight quality standards for each regency/city in the Province of North Sumatra.

Seeing the number of components in Accreditation and the information needed in the self-school evaluation process is quite a lot, the school needs to clearly understand what needs to be prepared in the accreditation assessment process. For this reason, there is a need for good communication within the environment carried out by BAN-S 
/ $\mathrm{M}$ to deliver policies and procedures that must be passed by each school to be accredited.

According to Subarsono (2008: 90-104) states that there are several theories that develop about the implementation of policies, namely; 1) George C. Edward III which consists of four stages of implementation including; (a) communication, (b) resources, (c) dispositions, (d) bureaucratic structures. Whereas Merilee S. Grindle which consists of two stages of implementation includes; (a) policy, (2) implementation environment. 3) Daniel A. Mazmanian and Paul A. Sabatier which consists of three stages of implementation including; a) characteristics of the problem, (b) characteristics of the policy, and (c) environmental variables. 4) Donald S. Van Meter and C. Van Hon, which consists of five stages of implementation including: (a) standards and policy tools, (b) resources, (c) communication, (d) agent characteristics. 5) Shabbir Cheema and Dennis A. Rondinell; (a) environmental conditions, (b) relationships between organizations, (c) resources, and (d) human resource characteristics.

Not all policies that are implemented can run well and correctly. The success of policy implementation will be determined by many variables or factors, and each of these variables is interconnected with one another. Subarsono (2008: 90-104) states that there are several theories developed about Policy Implementation, namely; George C. Edward III, Merilee S. Grindle, Daniel A. Mazmanian and Paul A. Sabatier, van Meter and van Horn, Cheema and Rondinelli, and David L. Weimer and Aidan R. Vining.

Regarding the factors that influence the implementation of a program's policies, Subarsono in his book entitled Public Policy Analysis (Concepts, Theories and Applications), cites the opinion of G. Shabbir Cheema and Dennis A. Rondinelli argues that there are several factors that influence the implementation of government policy policies which is decentralized. These factors include:

a) Environmental conditions

The environment greatly influences the implementation of policies, which means that this environment includes the socio-cultural environment and the involvement of program recipients.

b) Relations between organizations

In many programs, the implementation of a program needs support and coordination with other agencies. For this reason, coordination and cooperation between agencies is needed for the success of a program.

c) Organizational resources for program implementation Policy implementation needs to be supported by both human and non-human resources. 
d) Characteristics and capabilities of implementing agencies

What is meant by the characteristics and capabilities of implementing agencies is to cover the bureaucratic structure, norms, and patterns of relationships that occur in bureaucracy, all of which will affect the implementation of a program. (Subarsono, 2005: 101)

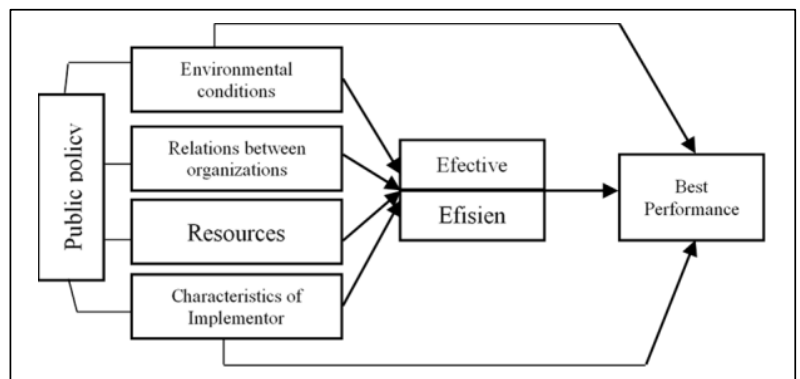

Figure 1. The Process of Public Policy Implementation according to G. Shabbir Cheema and Dennis A. Rondinelli

Based on the description above from a number of available public policy theories, this research is focused on the implementation of the Secondary School Accreditation policy in the City of Pematangsiantar by using policy implementation theory according to Shabbir Cheema and Dennis A. Rondinell.

The difference between this research and previous research conducted by Windari (2018) on accreditation policy in public elementary schools in the Medan Area Subdistrict is that Windari's study examines accreditation policy in terms of George C. Edward III's theory by looking at aspects of communication, resources, disposition, and bureaucratic structure. While this study looks at how a school accreditation policy is analyzed in terms of environmental conditions, inter-organizational relationships, resources and characteristics of the policy implementers.

\subsection{Significance of the study}

The results of this study will be beneficial to the school acreditation assesor, the school, the principals, and the public in general. For the school acreditatio it should given feed back to evaluate the acreditation system which they have and already done. For the school it will give an evaluation for a better service further. For the principal it will be a result academic supervision and gives good impact to revitalize and develop his leadership of school. For the public it will be a standard of a school to get education and service. 


\subsection{Scope and Limitation of the study}

Due to short time and financial, this study recognizes limits not only in terms of its scope and focus but also in its statistical tools, time frame, sampling methods, and others. On its scope it focused only on the analysis Junior High School Accreditation Policy in Pematangsiantar City according to Shabbir Cheema and Dennis A. Rondinelli, namely focused on relations between organizations, resources, and characteristics of human resources using public policy theory.

\subsection{Setting of the study}

The research was conducted in Junior High School in Pematangsiantar, North Sumatra Indonesia whic held on 51 Schools.

\section{Methodology}

This research uses a qualitative approach. In this research approach tends to be based on efforts to express and formulate field data in the form of words and describe the original reality and then the data is analyzed and abstracted in the form of theory as a final goal. To obtain the required data, the authors use interview and documentation techniques, and observation.

The data analysis technique is taxonomic analysis. Where taxonomic analysis is an analysis of the overall data collected based on a predetermined domain (Sugiyono, 2008: 356). Qualitative data are generally in the form of words or statements about something stated in the form of explanations in words or writing. For that the writer must analyze in the form of words or writing. The analysis process is: data reduction, data display, and conclusion drawing / verification (Sugiyono, 2008: $337)$.

\section{Results and Discussion}

The implementation of school/madrasah Accreditation policy In order to improve the quality of national education in stages, planned and measured in accordance with the mandate of Law Number 20 Year 2003 concerning the National Education System, CHAPTER XVI Part Two Article 60 The Government has established the National Accreditation Board for Schools/Madrasas (BAN -S / M) with Minister of Education Regulation Number 29 of 2005. 
A. Results of the Implementation of Accreditation Policy in Junior High Schools in Pematangsiantar City

Policy implementation will not begin until all objectives and targets have been determined or identified by policy decisions. Implementation is a process of activities carried out by the implementers of the Accreditation so that in the end it will get an outcome that is in accordance with the goals or objectives of the policy itself.

In this study, the approach used in analyzing the implementation of School / Madrasah Accreditation Policies in Pematangsiantar City Middle School is a theory put forward by G. Shabbir Cheema and Dennis A. Rondinelli. In the view of G. Shabbir and Dennis there are four factors that influence public policy, namely communication, resources, disposition and bureaucratic structure. The influence of these four factors on the implementation of the school / madrasah Accreditation policy is as follows:

1) Environmental Conditions

What is meant by this environment includes the socio-cultural environment and the involvement of program recipients. Supporting general environmental conditions in the Pematangsiantar city is very good. All aspects of the community around the school play an important role in achieving the accreditation value of the surrounding schools.

2) Relationships between Organizations

In many programs, the implementation of a program needs support and coordination with other agencies. For this reason, coordination and cooperation between agencies is needed for the success of a program. SMP in Pematangsiantar city, in addition to the education office, a good form of relationship exists between the school and other related institutions such as the Social Service, Health Service, Bina Marga Office, and Regional Library and State Archives.

3) Human Resources (HR)

Implementation of policies needs to be supported by resources, both human resources and non-human resources. Resources are chosen as factors that influence the success of policy implementation because the implementation of policies requires the support of human resources as well as budget/financial resources. The number of human resources in the Pematangsiantar City KPA-S / M is 5 people, consisting of 1 coordinator, and 4 members who go into the field to carry out all the process of implementing the accreditation policy which is assisted by 2 to 3 assessors. 
4) Characteristics and capabilities of the implementer

What is meant by the characteristics and capabilities of the implementer includes bureaucratic structure, norms, and patterns of relationships that occur in bureaucracy, all of which will affect the implementation of a program.

Disposition in this research is the willingness, desire and tendency of the actors to carry out the policy seriously so that what the policy objectives can be realized. Indicators of disposition in implementation consist of Recruitment Coordinator for School Accreditation and Incentives.

The Organizational Structure of KPA-S / M Pematangsiantar City simply illustrates clearly the work activities between one and the other and how the relationship of activities and functions is not restricted. In this organizational structure the coordination pattern that is established places the Head of the National Accreditation Board (BAN) as the highest official in which each part of the organization consists of the chairman, coordinator, and members who are connected with the direct chain of command from the center / national to the province to the sub-district.

\section{Discussion on Policy Implementation}

Regarding the factors that influence the implementation of a program's policy, Subarsono, 2005: 102 links several factors related to the theory stated by G. Shabbir Cheema and Dennis A. Rondinelli, namely:

Environmental conditions, namely something related to the type and system of policies, the structure of policy making, the characteristics of policies, constraints obtained by resources, socio-cultural, the degree of involvement of program recipients, and the availability of adequate physical infrastructure.

Inter-Organizational Relationship, which is related to the clarity and consistency of program objectives, the division of functions between appropriate agencies, standardization of planning, budgeting, implementation and evaluation procedures, accuracy, consistency and quality of communication between agencies, and the effectiveness of networks to support programs.

Organizational Resources is something related to the control of the source of funds, the balance between the distribution of the budget and program activities, the accuracy of budget allocations, sufficient income for expenditure, support from central political leaders, support from local political leaders, and 
bureaucratic commitment.

Characteristics and Capabilities of Implementing Agencies is something related to the technical, managerial and political skills of the officers. The ability to coordinate, control and integrate decisions. Political support and resources of the agency. The nature of internal communication. Good relations between agencies and target groups. Relationship with outside parties. The quality of the leaders of the agencies concerned. The officers' commitment to the program, and finally, is the position of the agency in the administrative system hierarchy.

\section{Conclusion}

From the research findings and discussion, some conclusions can be obtained:

a) Environmental Conditions Supporting general environmental conditions in the Pematangsiantar city is very good. All aspects of the community around the school play an important role in achieving the accreditation value of the surrounding schools.

b) Relations between Organizations

SMP in Pematangsiantar city, in addition to the education office, a good form of relationship exists between the school and other related institutions such as the Social Service, Health Service, Bina Marga Office, and Regional Library and State Archives.

c) Human Resources (HR)

The number of human resources in KPA-S / M of Pematangsiantar City is 6 people, consisting of 1 coordinator, and 5 members who go into the field to carry out all the process of implementing the accreditation policy which is assisted by 2 to 3 assessors.

d) Characteristics and capabilities of the implementer

The characteristics and capabilities of the SMP accreditation policy implementer in Pematangsiantar city are quite good, it can be seen from the disposition support in the form of the willingness, desire and tendency of the actors to implement the policy seriously so that what the policy objectives can be realized.

Organizational Structure in KPA-S / M Pematangsiantar City simply illustrates the work activities between one and another and how the relationship of activities and functions are not restricted. In this organizational structure the coordination pattern that is established places the Head of the National Accreditation Board (BAN) as the highest official in 
which each part of the organization consists of the chairman, coordinator, and members who are connected with the direct chain of command from the center / national to the province to the sub-district.

\subsection{Suggestion}

a. North Sumatra BAP-SM and KAP-S/M of Pematangsiantar City Direct socialization regarding activities related to junior high school accreditation is not only to the elements of school management, but also to the whole community (parents / guardians of students) as well, so that the community receives education on the significance of Accreditation.

b. Principal Target

The headmaster should be aware that the Accreditation program is not just the acquisition of grades A, B, C and Not Accredited, but how all school personnel should be able to improve the quality of schools in order to improve the quality of school output in accordance with the national education goals formulated by each school into form of vision, mission, and goals of the school.

c. Need for further research. This research is still based on the results of interviews, documentation and observations that are limited in time so that it is still possible to see a more comprehensive and thorough implementation of the implementation of the Accreditation effort.

\section{References}

Ministry of National Education. 2003. Republic of Indonesia Law No.20 of 2003 on the system

National Education

Badan Akreditasi Nasional Sekolah/Madrasah. Pedoman Akreditasi. Jakarta: Badan Akreditasi Nasional Sekolah/Madrasah (BAN S/M). 2014.

A.G Subarsono.2008. Analisis Kebijakan Publik. Yogyakarta : Pustaka Pelajar. pg 90-104

A. G Subarsono, 2005. Analisis Kebijakan Publik Konsep, Teori dan Aplikasi. Yogyakarta : Pustaka Pelajar. Pg.101

Cheema, G Shabbir \& Rondinelli, Dennis A, 1983, “Decentralization and Development", Sage Publication, Inc 
Windari (2018). Implementation Of School Accreditation Policy at State Elementary School in Medan Area Districts. Advances in Social Science, Education and Humanities Research, volume 200. [ONLINE) https://doi.org/10.2991/aisteel18.2018.187. https://download.atlantis-press.com/proceedings/aisteel$\underline{18 / 55909232}$ 